\title{
Evaluation of Social Benefits for Thermal Power Enterprise Standardization -Taking Panshan Power for Example
}

\author{
Hui Liu \\ China National Institute of Standardization, Beijing, 100191, China \\ Liuhui2604@163.com
}

\begin{abstract}
Social benefits of standardization are the non-economic social and environmental effects and interests produced by standardization. For thermal power enterprises, such benefits mainly comprise two parts, i.e. environmental protection and energy conservation. This paper takes Tianjin Datang International Panshan Power Generation Co., Ltd. as an example to assess the social benefits of standardization of thermal power enterprises by analyzing the social benefits produced by standardization during production from 2011 to 2014. The standardization activities launched by Panshan Power Generation Co., Ltd. significantly reduce emission concentration per unit space of air pollutants such as sulfur dioxide, nitrogen oxides and fume on one hand; and notably cut down the net coal consumption rate and water consumption rate on the other hand. Therefore, standardization has brought about remarkable social benefits to Panshan Power Generation Company.
\end{abstract}

Keywords: Thermal Power Enterprises, Standardization, Social Benefit, Evaluation.

\section{Introduction}

The conditions of China decide that our energy structure mainly relies on thermal power. In recent years, the rapid growth of national economy has stipulated the rapid development of thermal power generation in China. Thermal power enterprises are major sources of atmospheric pollutants emission, and also major consumers of energy sources such as coal, water, etc. Hence, thermal power enterprises have a great impact on environmental pollution and energy consumption. As everyone knows, promotion of national economic by standardization is not just manifested by the economic benefits it produces, but more importantly by its social benefits. However, the study on social benefits of standardization has obviously lagged behind the study on economic benefits, very few both in amount and findings.

Some Chinese and foreign scholars have studied on the relationship between standardization and environmental protection. Ian MacGregor-Fors (2011) explored the importance of standardization to urban eco-landscape planning. Chen Hongjian (2004) analyzed the effective ways to sufficiently bring the function of standardized agriculture into play in the Construction and Protection of Eco-environment of Areas Surrounding Scenic Spots. In his opinion, standardized agriculture is an integrated fundamental technical work for the realization of agricultural modernization, and the implementation of standardized agriculture is to the benefit of reasonable resource utilization, eco-environmental and health protection and social-economic benefit improvement. Xu Qing, et al (2005) expressed in their study on the effect of standardization on the recycle of mineral resources that standardization can effectively promote the comprehensive utilization of mineral resources, improve the resource utilization rate, and reduce the environmental pollution of barren rocks and waste water in mining. Wang Binbin (2009) analyzed the problems existing in the China's current standard environmental protection system based on the present situation of standardized environmental protection in China, and studied on building and improvement of a new standard environmental protection system. 


\section{Analysis on Social Benefits of Standardization in Tianjin Datang International Panshan Power Generation Co., Ltd.}

Co-founded by Datang International Power Generation Co., Ltd. with 75\% contribution and Tianjin Energy Investment Group Co., Ltd. with 25\% contribution, Tianjin Datang International Panshan Power Generation Co., Ltd. (hereinafter referred to as Panshan Power Generation Company) is constructed with two 600MW subcritical coal-fired steam turbo sets manufactured in China, which were the earliest to put into production in Beijing-Tianjin-Tangshan gird. The construction of the Panshan Power Generation Project was commenced in November 1998, and the two sets were respectively put into commercial operation on December 18, 2001 and June 5, 2002.

\subsection{Definition of Social Benefits of Standardization in Panshan Power Generation Company}

For thermal power enterprises, their social benefits are mainly manifested by their beneficial effects in environmental protection, energy conservation and consumption reduction. In comparison with environmental protection, energy conservation and consumption reduction, their promotion for the development and progress of science, technology, culture, social welfare and public interests are relatively not so direct and apparent. The social evaluation indicators of thermal power enterprises are designed to highlight the characteristics of thermal power industry. As thermal power enterprises generate certain impacts on surrounding environment during their development, environmental protection is particularly emphasized at the principle level of social benefit evaluation indicators for standardization, such as indictors for resource environment and ecological environment, and the social benefit characteristics of the thermal power industry are also highlighted through the integration of universality and exclusiveness. To this end, the evaluation on social benefits of standardization under this project is only limited to the impacts of standardization on environmental protection, energy conservation and consumption reduction.

\subsection{Composition of Social Benefits of Standardization in Panshan Power Generation Company}

The social benefits of standardization at Panshan Power Generation Company are mainly shown in environmental protection, energy conservation and consumption reduction. In terms of environmental protection, coals fired at thermal power plants produce pollutants such as sulfur dioxide, nitrogen dioxide, fume, soot, etc. Among various pollutant sources, sulfur dioxide in the exhaust fume of thermal power plants is of low concentration but the largest amount. Thermal power generation is the major player to be blamed for sulfuric acid smog and acid rain. The main indicators for evaluating the environmental protection effects of a company include the emission loads of atmospheric pollutants, such as sulfur dioxide, nitrogen dioxide, soot, etc. In terms of energy conservation and consumption reduction, as thermal power plants are big energy consumers and consume large amounts of coal, water and fuel for power generation every year, coal consumption and water consumption for power supply are selected as the main indicators for evaluating their emission reduction effect.

In recent years, Panshan Power Generation Company has made great efforts in energy conservation and environmental protection oriented construction and operation, mainly including the management of four consumption indicators (coal, electric power, water and oil consumptions), the management of indicators for four emissions and one rate (sulfur dioxide, nitric oxide, soot, wastewater and efficiency), economical evaluation activities and so on, and implemented strict control over sulfur dioxide, nitric oxide, soot, wastewater, etc. to ensure zero incident in environmental protection evaluation. Among other things, the energy conservation and environmental protection of Panshan Power Generation Company involve desulfurization, denitration, dust removal, coal conservation, water conservation and power conservation under 93 national standards, 67 industrial standards and 21 enterprise standards. 


\section{Analysis On Impacts of Standardization on Environmental Protection of Panshan Power Generation Company}

\subsection{Emission of Atmospheric Pollutants by Panshan Power Generation Company}

The emissions of atmospheric pollutions by Panshan Power Generation Company in 2011-2014 are as shown in Table 1.

Table 1. Emission statistics of atmospheric pollutants in 2011-2014

\begin{tabular}{|c|c|c|c|c|c|c|}
\hline $\begin{array}{l}\text { Atmospheric } \\
\text { pellutants } \\
\text { Year }\end{array}$ & $\begin{array}{c}\text { Sulfur } \\
\text { dioxide, } \mathrm{t}\end{array}$ & $\begin{array}{c}\text { Sulfur } \\
\text { dioxide, } \\
\text { mg/standard } \\
\text { cubic meter }\end{array}$ & $\begin{array}{l}\text { Nitric } \\
\text { oxide, } t\end{array}$ & $\begin{array}{l}\text { Nitric oxide, } \\
\text { mg/standard } \\
\text { cubic meter }\end{array}$ & Dust, $\mathrm{t}$ & $\begin{array}{c}\text { Dust, } \\
\text { mg/standard } \\
\text { cubic meter }\end{array}$ \\
\hline 2011 & 2326.05 & 83.96 & 8125.42 & 361.39 & 574.92 & 20.31 \\
\hline 2012 & 1762.89 & 88.85 & 6868.6 & 361.82 & 352.71 & 19.04 \\
\hline 2013 & 1523.29 & 75.56 & 3742.88 & 211.32 & 372.99 & 19.68 \\
\hline 2014 & 1129.97 & 47.44 & 1479.05 & 65.2 & 344.95 & 15.28 \\
\hline
\end{tabular}

As shown in Table 1, in 2011-2014, the volumes and concentrations of sulfur dioxide, nitric oxide and dust emitted by Panshan Power Generation Company declined year by year.

\subsection{Analysis on Impacts of Standardization on Environmental Protection of Panshan Power Generation Company}

Panshan Power Generation Company strictly implements standards on environmental protection to control the emissions of atmospheric pollutants within the range of specified indicators. Before 2014, it applied the Emission Standard of Air Pollutants for Boiler (DB 12151-2003) for emissions of atmospheric pollutants, in which, the emission criteria for sulfur dioxide, nitric oxide and soot are 200mg/Nm3, 400mg/Nm3 and 80mg/Nm3 respectively (effective as of January 1, 2006). Since 2014, it has applied a new standard, the Emission Standard of Air Pollutants for Thermal Power Plants (GB 13223-2011), for emissions of atmospheric pollutants, in which, the emission criteria for sulfur dioxide, nitric oxide and soot are $200 \mathrm{mg} / \mathrm{Nm} 3,100 \mathrm{mg} / \mathrm{Nm} 3$ and $30 \mathrm{mg} / \mathrm{Nm} 3$ respectively. In comparison, the national standard GB 13223-2011 is much stricter on nitric oxide and soot emission indicators than DB 12151-2003, which are respectively reduced from $400 \mathrm{mg} / \mathrm{Nm} 3$ and $80 \mathrm{mg} / \mathrm{Nm} 3$ to $100 \mathrm{mg} / \mathrm{Nm} 3$ and $30 \mathrm{mg} / \mathrm{Nm} 3$. In order to achieve the emission indicators specified in the new standard, it invested for technical transformation of environmental protection. It invested 180 million yuan for denitration equipment during 2012-2013, and another 65 million yuan in 2014 for desulfurization capacity expansion. After the application of the new standard from 2014, its emission volumes and concentrations of sulfur dioxide, nitric oxide and soot have been reduced obviously.

Comparing the emissions in 2011 when the old standard was applied with those in 2014 after the application of the new standard, the emissions of sulfur dioxide, nitric oxide and soot were reduced by $36.52 \mathrm{mg} / \mathrm{Nm} 3,296.19 \mathrm{mg} / \mathrm{Nm} 3$ and $5.03 \mathrm{mg} / \mathrm{Nm} 3$ respectively, i.e. a reduction of $43.49 \%, 81.95 \%$ and $24.76 \%$ respectively. Comparing with 2012 when the old standard was applied, the emissions of sulfur dioxide, nitric oxide and soot were reduced by $41.41 \mathrm{mg} / \mathrm{Nm} 3,296.62 \mathrm{mg} / \mathrm{Nm} 3$ and $3.76 \mathrm{mg} / \mathrm{Nm} 3$ respectively, i.e. a reduction of $46.6 \%, 81.98 \%$ and $19.75 \%$ respectively. Comparing with 2013 when the old standard was applied, the emissions of sulfur dioxide, nitric oxide and soot were reduced by $28.12 \mathrm{mg} / \mathrm{Nm} 3,146.12 \mathrm{mg} / \mathrm{Nm} 3$ and $4.4 \mathrm{mg} / \mathrm{Nm} 3$ respectively, i.e. a reduction of $37.2 \%, 69.14 \%$ and $22.36 \%$ respectively.

To calculate with the electricity generated in entire 2014, its pollutant emissions were remarkably reduced in comparison with those when the old environmental standard was applied. In comparison with 2011, the emissions of sulfur dioxide, nitric oxide and soot respectively reduced by 1,146.61 t, $6,473.55 \mathrm{t}$ and $217.74 \mathrm{t}$; in comparison with 2012, the emissions of sulfur dioxide, nitric oxide and 
soot respectively reduced by $731.12 \mathrm{t}, 5,772.16 \mathrm{t}$ and $27.41 \mathrm{t}$; in comparison with 2013 , the emissions of sulfur dioxide, nitric oxide and soot respectively reduced by $436.21 \mathrm{t}, 2,369.22 \mathrm{t}$ and $38.54 \mathrm{t}$. Averagely, Panshan Power Generation Company realized an annual sulfur dioxide reduction of 771.31 $\mathrm{t}$, an annual nitric oxide reduction of 4,871.65 $\mathrm{t}$ and an annual soot reduction of $94.56 \mathrm{t}$, as shown in Table 2.

Table 2. Emission reduction statistics of atmospheric pollutants under old and new standards

\begin{tabular}{ccccccc}
\hline $\begin{array}{c}\text { Atmospheric } \\
\text { polutants }\end{array}$ & $\begin{array}{c}\text { Sulfur } \\
\text { dioxide, } \mathrm{t}\end{array}$ & $\begin{array}{c}\text { Sulfur } \\
\text { dioxide, } \\
\text { mg/standard } \\
\text { cubic meter }\end{array}$ & $\begin{array}{c}\text { Nitric } \\
\text { oxide, } \mathrm{t}\end{array}$ & $\begin{array}{c}\text { Nitric oxide, } \\
\text { mg/standard } \\
\text { cubic meter }\end{array}$ & Soot, t & $\begin{array}{c}\text { Soot, } \\
\text { mg/standard } \\
\text { cubic meter }\end{array}$ \\
\hline 2011 & 1146.61 & 36.52 & 6473.55 & 296.19 & 217.74 & 5.03 \\
2012 & 731.12 & 41.41 & 5772.16 & 296.62 & 27.41 & 3.76 \\
2013 & 436.21 & 28.12 & 2369.22 & 146.12 & 38.54 & 4.4 \\
2014 & -- & -- & -- & -- & -- & -- \\
\hline
\end{tabular}

\section{Analysis on Impacts of Standardization on Energy Conservation and Consumption Reduction of Panshan Power Generation Company}

\subsection{Energy Consumption}

As it realized plasma ignition from 2009 and fuel ignition was no longer used, the fuel consumption is not included in the energy consumption statistics. The energy consumption statistics in 2011-2014 are as given in Table 3.

Table 3. Production energy consumption statistics in 2011-2014

\begin{tabular}{|c|c|c|c|c|c|}
\hline Year & $\begin{array}{c}\text { Standard } \\
\text { coal, } \mathrm{t}\end{array}$ & Groundwater, $\mathrm{t}$ & Surface water, $\mathrm{t}$ & $\begin{array}{c}\text { Coal consumption for } \\
\text { power supply, g/kWh }\end{array}$ & $\begin{array}{c}\text { Integrated water } \\
\text { consumption, } \\
\mathrm{kg} / \mathrm{kWh}\end{array}$ \\
\hline 2011 & 2082539 & 905940 & 15294214 & 320.49 & 2.29 \\
\hline 2012 & 1931904 & 904528 & 13627898 & 320 & 2.2 \\
\hline 2013 & 1971778 & 877569 & 13282335 & 318.2 & 2.11 \\
\hline 2014 & 1996125 & 780807 & 13007022 & 313.69 & 1.99 \\
\hline
\end{tabular}

As shown by the statistical data in Table 3, the unit power-supply energy consumption of Panshan Power Generation Company showed a descending trend year by year.

\subsection{Analysis on Impacts of Standardization on Energy Conservation and Consumption Reduction of Panshan Power Generation Company}

The work of energy conservation and consumption reduction of enterprises is a systematic work. Panshan Power Generation Company has initiatively reduced the energy consumption through technical modification of equipment in recent years. In 2013, it invested 260.38 million yuan for 41 major projects, and the turbine heat rate reached the design value and the coal consumption for power supply reduced remarkably through upgrading and replacement of the main equipment. In the meantime, it completed the cascade water consumption works of industrial wastewater recovery and treatment, reconstruction of desulfurization system cooling water and reconstruction of dedusting air compressor cooling water recovery, and saved about 1,600 t cooling water every day. In 2014, it saved 79,570 t energies through measures such as reduction of coal consumption, electric energy substitution, unit load correction, etc. 
To calculate with the electricity generated in entire 2014, its power-supply coal consumption reduced by $6.8 \mathrm{~g} / \mathrm{kWh}$ in comparison with 2011, equivalent to 45,811.6t standard coals in total, and to calculate with the 2014 arrival unit price of standard coal, it saved 22.6781 million yuan from fuel coal conservation. In comparison with 2012 , its power-supply coal consumption reduced by $6.31 \mathrm{~g} / \mathrm{kWh}$, equivalent to $42,510.47 \mathrm{t}$ standard coals in total, and to calculate with the 2014 arrival unit price of standard coal, it saved 21.044 million yuan from fuel coal conservation. In comparison with 2013, its power-supply coal consumption reduced by $4.51 \mathrm{~g} / \mathrm{kWh}$, equivalent to $30,383.87 \mathrm{t}$ standard coals in total, and to calculate with the 2014 arrival unit price of standard coal, it saved 15.041 million yuan from fuel coal conservation. Averagely, it saved 39,568.65 t fuel coals each year,a cost reduction of19.5877 million yuan.

To calculate with the electricity generated in entire 2014, its groundwater usage and surface water usage reduced by $105,864.96 \mathrm{t}$ and $1,961,906.11 \mathrm{t}$ respectively in comparison with 2011 , i.e. a total water consumption reduction of 2,067,771.07 t, about 8.135 million yuan. In comparison with 2012, its groundwater usage and surface water usage reduced by 174,107.52 $\mathrm{t}$ and 1,380,014.82 $\mathrm{t}$ respectively, i.e. a total water consumption reduction of 1,554,122.34 t, about 5.9919 million yuan. In comparison with 2013, its groundwater usage and surface water usage reduced by $121,471.88 \mathrm{t}$ and $649,306.26 \mathrm{t}$ respectively, i.e. a total water consumption reduction of $770,778.13 \mathrm{t}$, about 2.9264 million yuan. Averagely, it saved 1,464,223.85 t water each year, a cost reduction of about 5.6842 million yuan. The specific data are as shown in Table 4.

Table 4. Energy consumption reduction statistics in 2011-2014

\begin{tabular}{|c|c|c|c|c|c|}
\hline Year & Standard coal, $\mathrm{t}$ & Groundwater, $\mathrm{t}$ & Surface water, $\mathrm{t}$ & $\begin{array}{c}\text { Power-supply coal } \\
\text { consumption, g/kWh }\end{array}$ & $\begin{array}{c}\text { Integrated } \\
\text { water } \\
\text { consumption, } \\
\mathrm{kg} / \mathrm{kWh}\end{array}$ \\
\hline 2011 & 45811.6 & 105864.96 & 1961906.11 & 6.8 & 0.3 \\
\hline 2012 & 42510.47 & 174107.52 & 1380014.82 & 6.31 & 0.21 \\
\hline 2013 & 30383.87 & 121471.88 & 649306.26 & 4.51 & 0.12 \\
\hline 2014 & - & - & - & -- & -- \\
\hline
\end{tabular}

\section{Conclusion}

In this paper, we analyzed the theories and characteristics of social benefits of standardization, and took Panshan Power Generation Company as an example to analyze the impacts of standardization on its environmental protection, energy conservation and consumption reduction, to estimate the volume-value of social benefits of standardization at enterprises and provide empirical bases for evaluating the social benefits of standardization at thermal power enterprises. Of course, there's a defect in the estimations we made herein for social benefits of standardization. For instance, for the reductions of atmospheric pollutant emissions and the reductions of unit energy consumptions for power generation of Panshan Power Generation Company, we approximately considered them all as the benefits from implementing the standards. However, the actual conditions were not the case, and such reductions were also the result of factors such as technical modification, equipment upgrading, etc. How to strip the impacts of the standard factor will be the direction for our further researches and studies in the future.

\section{Acknowledgements}

This research was financially supported by the President Foundation of CNIS (572016Y-4676) and National Natural Foundation (71373137). 


\section{References}

[1] Ian MacGregor-Fors. (2011). Misconceptions or misunderstandings? On the standardization of basic terms and definitions in urban ecology. Landscape and Urban Planning 100: 347-349.

[2] Chen Hongjian.(2004). Agricultural Standardization and Construction and Protection of Eco-environment of Areas Surrounding Scenic Spots. Journal of Anhui Agricultural Sciences, 32(1):176-178

[3] Xu Qing, Lan Jingzhi, Li Jian. (2005). Discussions on Standardization and Mineral Resource Recycle. Technology and Management,(1):1-4..

[4] Wang Binbin. (2009). New Thinking for Standardization of Environmental Project in China. Quality and Technical Supervision Research, (3). 17-21. 